\title{
LITERATURA ÎN LIMBA ROMÂNĂ - O MARCĂ IDENTITARĂ A COMUNITĂȚII ROMÂNEȘTI DIN UNGARIA
}

\author{
IUDIT CÄLINESCU \\ Universitatea de Științe din Szeged, Ungaria
}

\begin{abstract}
Rezumat. Literatura în limba română din Ungaria s-a dezvolat în interiorul comunității românești de aici. Fiind o literatură minoritară, tematica ei este marcată de criza identitară, de dorința de întoarcere în satul tradiţional, de teama pierderii identităţii şi de tragismul crizei valorilor general umane. După ce în perioada interbelică românii din Ungaria au rămas aproape fără intelectuali, singura formă de manifestare literară fiind literatura populară, după 1960 încep să apară primele creații culte, în principal poezie și proză scurtă. Scriitorii români din Ungaria publică in revistele care sunt editate în comunitate, lipsindu-le un cenaclu literar sau reviste de literatură, creațiile lor devenind în ultimele decenii o marcă identitară și o formă de prezervare a limbii materne.
\end{abstract}

Cuvinte cheie: comunitate etnică, minoritate, identitate, literatură, folclor.

Abstract. Romanian literature in Hungary developed within the Romanian community here. Being a minority literature, its theme is marked by the identity crisis, the desire to return to the traditional village, the fear of losing identity and the tragedy of the crisis of general human values. After the Romanians in Hungary were left without intellectuals in the interwar period, the only form of literary manifestation being popular literature, after 1960 the first cult creations began to appear, mainly poetry and short stories. Romanian writers in Hungary publish in magazines that are published in the community, lacking a literary circle or literature magazines, their creations becoming in recent decades an identity mark and a form of preservation of the mother tongue.

Keywords: ethnic community, minority, identity, literature, folklore.

Atunci când se dorește analizarea unei comunităţi dintr-o perspectivă culturală, este necesar un demers istoric pentru a putea evidenția specificitatea devenirii ei, în special atunci când este vorba despre o comunitate etnică așa cum este cea românească din Ungaria. Iar când vorbim despre cultură într-o comunitate trebuie să pornim de la ideea de „societate globală” împărțită în „societăți parțiale”, societatea dominantă transformând cultura de naţionalitate într-o subcultură a celei dintâi (Radkowski, 2000, p. 65-67). Peisajul cultural contemporan nu este omogen sau unitar, fiind generate „subculturi” specifice care se întrepătrund și se influențează reciproc, fiecare câmp cultural fiind legat de o anumită categorie socială, pe criterii diverse, o astfel de subcultură 
putând fi considerată și cea din comunitățile etnice minoritare (Coman, 1999, p. 18). Astfel încât, pentru a analiza cultura unui grup etnic trebuie să avem în vedere faptul că identitatea culturală colectivă se formează prin educație și este transmisă prin căi formale, informale sau nonformale fiecărui membru al comunității, (Raliade, 2004, p. 35), contribuind nu doar la păstrarea unei coeziuni a comunității ci și la prezervarea unei identități culturale și etnice. De asemenea, atunci când vorbim despre culturile comunităților etnice nu trebuie să uităm faptul că acestea sunt diferite chiar dacă de multe ori comunitățile sunt juxtapuse în spațiu(Lévi-Strauss, 2001,p. 12), specificitățile culturale rămânând unele dintre elementele de bază prin care se poate diferenția o comunitate etnică de alta, devenind astfel puternici indici identitari ai comunității. Diversitatea culturală nu trebuie văzută în mod static, ea modificându-se în funcție de elementul geografic, istoric și social, nicio comunitate nedezvoltându-și cultura izolat față de alte comunități învecinate, existând mereu transformări sau împrumuturi culturale transmise de la o comunitate la alta (Lévi-Strauss, 2001, p. 15-16). În același timp, recunoașterea diversității culturilor umane nu trebuie să împiedice să considerăm cultura ca o ,caracteristică fundamentală a existenței în societate a tuturor oamenilor" (Giraud, 1999, în Ferréol, 1999, p. 64).

Pornind de la aceste perspective asupra culturii, în special asupra culturii comunităților etnice, se pot formula câteva idei legate de specificitatea culturii comunității românilor aflați în prezent pe teritoriul Ungariei, vorbind aici atât despre o comunitate istorică românească, formată din români care trăiesc în localităti aflate lângă granița vestică a României, rămase pe teritoriul Ungariei după modificările granițelor în urma Tratatului de la Trianon din 1920, dar și despre o comunitate de diaspora românească din Ungaria, formată din români care au migrat în această țară, în special în perioada postbelică. Iar una din specificităţile culturale ale acestei comunități etnice, în special în ultimele decenii, este legată de fenomenul multiculturalismului, acesta reprezentând o consecință a unei evoluții ireversibile și a unei rupturi în istoria societății contemporane (Pierrot, 1999, în Ferréol, 1999, p. 144). Multiculturalismul a reprezentat pentru comunitatea românească din Ungaria un fenomen care a grăbit pierderea identității românești și asimilarea treptată a acestui grup etnic. Deși este un fenomen inevitabil, specific epocii moderne, mai ales într-o zonă în care au coexistat dintotdeauna mai multe culturi care au intrat mereu în contact, fie că e vorba de cultura majoritară maghiară, fie de culturile etniilor minoritare (slovace, germane, sârbe, etc.), contactul cu acestea a dus în timp la multe împrumuturi și schimburi culturale de la una la cealaltă, în același timp ducând la multe pierderi din perspectiva identității culturale românești. De la multiculturalism, trecerea la fenomene ca aculturația, dubla identitate sau bilingvismul au reprezentat următorul pas, toate contribuind, mai mult sau mai puțin, la asimilarea tot mai rapidă a comunității românești din Ungaria. Insă dincolo de presiunile și tendințele de globalizare, hibridizare și multiculturalism ale societății contemporane (Mihăilescu, 2007, p. 22-23), 
cultura a fost și rămâne cea care a oferit o șansă de prelungire a vieții acestei comunităti etnice, fenomenul cultural, prin toate formele lui de manifestare, fiind unul din pilonii păstrării identității românești a comunității românilor din Ungaria. Iar o specificitate aparte a culturii românilor din Ungaria este dată de faptul că o marcă identitară importantă a fost întotdeauna reprezentată de cultura populară sub toate formele ei, ceea ce este firesc ținând cont de faptul că această comunitate a fost constituită pe temelii ale satului tradițional, care au rezistat până la mijlocul secolului al XX-lea. Din perspectiva folcloristului Alexandru Hoțopan cultura populară a românilor din Ungaria poate fi considerată parte integrată a culturii românești în general pentru că, dincolo de influențele și specificitățile datorate zonei geografice dar și istoriei românilor de aici, tezaurul folcloric al românilor din Ungaria reprezintă moștenirea naționalității române ca întreg (Hoțopan, 1982, p. 5).

În interiorul fenomenului cultural, literatura în limba română din Ungaria are o importanță deosebită, ea fiind nu doar o formă de manifestare artistică ci și o puternică marcă identitară, prin operele literare populare sau culte autorii oferind, alături de elemente de valoare artistică și de tematică specifică acestei comunități etnice, și o formă de prezervare și de promovare a limbii române, fie că e vorba de graiurile specifice comunității tradiționale sau de limba română literară. Trebuie punctat și faptul că în perioada interbelică această comunitate a rămas aproape fără intelectuali, aceștia migrând după 1920 în România, singura formă de manifestare literară rămânând astfel literatura populară. Urmând firul istoric, putem vorbi despre începuturile unei literaturi culte în limba română în Ungaria abia în perioada postbelică, primele decenii ale acestei perioade putând fi considerate însă „de noviciat”, mai ales din cauza lipsei unei intelectualități compacte care să iși asume actul creației (Munteanu, 2009, p. 17). Primele semne de creație literară au loc în anii 19501960, odată cu apariția primei generații de intelectual români, însă Cornel Munteanu situează începutul literaturii moderne a românilor din Ungaria abia la începutul anilor 1970 (Munteanu, 2009, p. 17), scriitorii din acea perioadă aparținând în mare parte intelectualilor formați la catedrele de limba română ale universităților din Seghedin și Budapesta. Un alt aspect interesant legat de începuturile literaturii românești din Ungaria ține de faptul că aici scriitorii șiau început căutările artistice și afirmarea literară mai ales individual, lipsindule un cenaclu sau dezbateri literare, un mentor sau reviste de literatură, în mare parte publicând în Foaia noastră, singurul organ de presă al comunității în anii 1970. Iar o altă specificitate a literaturii de limbă română din acea perioadă istorică este legată de faptul că prioritățile comunitare se îndreptau mai ales înspre găsirea răspunsurilor legate de problemele minoritare, de căutarea identității și de păstrarea ei (Munteanu, 2009, p. 18).

Prima încercare de grupare a autorilor români din Ungaria într-un volum colectiv este realizată sub egida Uniunii Democratice a Românilor din Ungaria, care era în anii 1970 și editorul responsabil al publicației Foaia noastră, unde își publicau creațiile scriitorii din cadrul comunității. Astfel, în 
1973 apare volumul Muguri, care reprezintă o antologie de texte literare a unor autori din mai multe generații care încă nu aveau volume individuale publicate (Munteanu, 2009, p. 19). În prima parte a acestui volum sunt întrunite creații în proză și în versuri ale autorilor români din Ungaria - Petru Anton, Lucia Borza, Nicolae Gîndilă, Ioan Halász, Alexandru Hoțopan, Ilie Ivănuș, Lucian Magdu, Vasile Roxin, Gheorghe Santău - iar în a doua parte sunt adunate studii literare ale cercetătorilor români de aici - Gheorghe C. Mihăiescu, Alexandru Hoțopan, Gheorghe Petrușan, Sándor Márki - antologia dorindu-se a fi o modalitate prin care tinerii scriitori să găsească reunoașterea din partea comunității (Silaghi, 1973, p. 5).

După momentul Muguri literatura în limba română din Ungaria începe să prindă contur, în următoarele decenii scriitorii publicând atât în presa românească de aici cât și în volume individuale, abordând în special poezia și proza scurtă. Trebuie făcută precizarea că unii dintre acești scriitori publică atât în limba română cât și în limba maghiară, bilingvismul fiind o altă specificitate a literaturii românilor din Ungaria. Iar în ceea ce privește tematica abordată, un loc important îl are ceea ce Cornel Munteanu numește ca fiind „criza identitară” născută dintr-un anumit „,complex al minoritarului”, reprezentând de fapt o pierdere a reperelor care definesc identitatea etnică, ea fiind evidențiată mai ales în operele literare ale poeților bilingvi printr-o poezie interogativ-reflexivă „cu accente existențiale amare” (Munteanu, 2009, p. 74). Complexul identitar este alimentat și de cel al dizlocării temporale și spațiale a copilăriei, casa părintească, satul apărând ca fiind în părăsire, pierzându-se astfel legăturile care dau un sens vieții (Munteanu, 2009, p. 77). Iar un alt aspect interesant al literaturii de limbă română din Ungaria este reprezentat de faptul că scriitorii imaginează un topos specific zonei lor de origine, la care se adaugă un topos social, legat de conviețiirea cu diverse alte naționalități, dar și un topos al tradițiilor specifice comunității românești, ceea ce face să fie valorificată din plin creația populară, toate aceste elemente făcând din literatura românilor din Ungaria ,un spațiu cultural pe cât de pitoresc și neuniform, pe atât de incitant și surprinzător” (Munteanu, 2009, p. 26-27).

Fiind o comunitate etnică construită pe temeliile puternice ale unei comunități tradiționale, autarhice, putem afirma că această comunitate românească din afara granițelor și-a clădit fundația culturală și a rezistat identitar în primul rând prin folclor, tradiții și tot ce reprezintă patrimoniul material și imaterial românesc, literatura populară având astfel un rol deosebit de important, atât în perioada interbelică cât și în primele decenii postbelice. Literatura populară este reprezentată în primul rând prin creațiile marilor povestitori populari Vasile Gurzău, Mihai Purdi și Teodor Şimonca. Cei trei povestitori români, deși nu au un repertoriu extins de subiecte fantastice, ceea ce reprezintă o caracteristică regională, sunt reprezentativi pentru fenomenul povestitului în satele românești din Ungaria (Hedeșan, 2007, p. 9-10), ei ocupându-și, începând cu anii 1980, „locul cuvenit în bibliografia maghiară privitoare la studiul basmului" (Hedeșan, 2007, p. 18), influențând cultura 
și limba românilor de aici în mod direct, până la sfârșitul anilor 1980, și în mod indirect în anii următori, prin acțiunile de recuperare și revalorificare a povestirilor lor, realizate atât de folcloriști români cât și de maghiari. Basmele lor au fost transmise pe cale orală timp de multe decenii, în graiul popular specific locului, dovedind dragostea și respectul comunitătilor de români din Ungaria pentru acest tip de act cultural și pentru valorile autentice populare românești (Hoțopan, 1982, p. 5). Cei trei povestitori aduc în basmele lor specificul local al satelor din care provin - Micherechi, Otlaca Pustă și Chitighaz - utilizând graiurile populare folosite în respectivele localități (Munteanu, 2009, p. 82). Între anii 1963-1982 au fost publicate șase colecții de basme culese de la povestitori români din Ungaria, inclusiv în traducere maghiară, în aceste volume apărând 45 de basme - 16 ale lui Gurzău, 12 ale lui Purdi și 17 ale lui Șimonca (Hedeșan, 2007, p. 5).

În ceea ce privește nucleul tematic identificat în aceste basme, se pot găsi similarități printr-o lectură comparativă cu basme din regiunile învecinate, cum ar fi cele culese de Ioan Slavici în zona Șiriei sau basme culese din Banatul de Câmpie, o posibilă explicație putând fi faptul că povestitorii au trăit evenimente similare în viaţă, asemănările fiind regăsite nu doar în structură, ci și în atmosfera basmelor, în recursul la aceleași situații sau fraze stereotipe (Hedeșan, 2007, p. 11-12). Subiectele acestora, fie fantastice fie nuvelistice, au ca temă centrală familia și onoarea acesteia iar miza întâmplărilor este reechilibrarea relațiilor de familie, dincolo de acest nucleu tematic fiind relevante detaliile numite de Domokos Sámuel „amănunte revelatoare”, în special ,geografia spațiilor pe care povestitorul le-a străbătut cu ocazia războiului" (Hedeșan, 2007, p. 13-14). Un element care oferă o specificitate aparte basmelor celor trei povestitori este atmosfera, specifică stilului regional, trecând de la lumea sălașelor din pustă la dorința de depășire a statutului social (slugă-stăpân), povestitorii având posibilitatea de a alege atât elemente din repertoriul românesc cât și din cel maghiar, alunecarea între limbi și culturi fiind însă diferită, de la un povestitor la altul (Hedeșan, 2007, p. 14-15).

Vasile Gurzău (1898-1980) s-a născut la Micherechi, într-o familie de țărani săraci. Domokos Sámuel, folcloristul maghiar care a cules și a publicat, atât în română cât și în maghiară, basmele lui Gurzău în 1963 și 1968, afirmă că încă din tinerețe Gurzău atrăgea oamenii cu basmele pe care le povestea la muncă, primele basme fiind auzite de la mama sa, apoi în întreaga sa copilărie de la bătrânii satului iar mai târziu de la alți povestitori (Domokos, 1985, p. 140-141). Arta povestirii lui Gurzău era caracterizată printr-o implicare activă a ascultătorilor, comunitatea satului cerându-i să-și spună poveștile cu fiecare ocazie posibilă, basmele cele mai cerute fiind povestite cu dialoguri dramatice și cu o narațiune bogată, având astfel ascultători activi, implicați în povestire, ei fiind cei care conduceau, prin întrebările lor, firul poveștii (Domokos, 1985, p. 142). Culegerea basmelor lui Vasile Gurzău a fost realizată de Domokos Sámuel pe o bandă de magnetofon, între 1959 și 1965, 17 texte fiind publicate în 1968, cu o transcriere fonetică ce respectă graiul micherechean - o variantă 
locală a graiului bihorean din subdialectul crișean (Bucin, 1999, p. 10). Mihai Purdi (1904-1978) s-a născut la Otlaca-Pustă, poveștile sale fiind culese de folcloristul Alexandru Hoțopan și editate în 1977, în volumul Poveștile lui Mihai Purdi. Sursa principală a basmelor lui Purdi este cea directă, el auzindu-le în copilărie de la bunicul său, însă spre deosebire de ceilalți doi povestitori, care practică intervenția subiectivă în text, poveștile sale au o doză mai mare de obiectivitate, naratorul adăugând personajelor mai multă naturalețe în gesturi și mișcări. Spațiul îl reprezintă lumea țărănească a sălașelor combinat cu lumea împărătească, el amestecând planul real cu cel imaginar, suprapunându-le sau inversându-le, temele predilecte fiind relațiile dintre părinți și copii, el punând accent pe afecțiunea, stările și sentimentele dintre ei. (Munteanu, 2009, p. 83-84). Trebuie menționat și faptul că Mihai Purdi a fost și un colaborator al publicațiilor românești din Ungaria iar în cadrul proiectului instituționalizat de culegere a folclorului românesc a publicat aici numeroase povestiri și snoave populare (Munteanu, 2006, p. 170). Teodor Șimonca (1899-1999) s-a născut în localitatea Chitighaz iar poveștile sale au fost culese și editate tot de folcloristul Alexandru Hoțopan, în volumele Florian - Poveștile lui Teodor Șimonca (1981) și Împăratu Roșu și Împăratu Alb (1982). Se poate vorbi despre o supratemă a basmelor sale, numită de Cornel Munteanu „comunitatea legată, în care relațiile dintre oameni fac parte din legile nescrise ale firii” (Munteanu, 2009, p. 25). Comuniunea nu se realizează prin poziția socială sau materială ci prin prețuirea adevărului, cinstei și omeniei, poveștile lui Șimonca având un mesaj moralizator, optimist și plin de valori spirituale (Munteanu, 2009, p. 25).

Literatura cultă în limba română din Ungaria se manifestă, în perioada postbelică, în principal prin poezie și proză scurtă, la care se adaugă studii de istorie și critică literară regăsite în contribuțiile cercetătorilor din cadrul Catedrei de Limba Română de la Universitatea „Eötvös Loránd” din Budapesta - Pálffy Endre, Domokos Sámuel, Ladislau Gáldi - cât și în studiile lui Gheorghe Petrușan, Tiberiu Herdean, Gh. C. Mihăiescu, Ion Popon sau Lucreția Șipoș Fluieraș. Cei mai importanți poeți ai comunității românești din Ungaria, care pe lângă alte forme de exprimare artistică sau cercetare istorico-culturală, au abordat și genul liric, sunt Lucian Magdu, Ilie Ivănuș, Ana Crișan, Lucia Borza, Alexandru Hoțopan și Maria Berényi. Proza în limba română este reprezentată în principal de Ilie Ivănuș, Gheorghe Santău, Petru Popuța, Ana Radici Repiski și Vasile Roxin (Munteanu, 2009, p. 26). Însă primele încercări de poezie ale reprezentanților intelectualității românești din Ungaria au apărut încă de la începutul secolului al XX-lea, când preotul ortodox Iosif Ioan Ardelean din Chitighaz publică la Arad, în 1902, volumul Buchetul meu, care deși nu are o deosebită valoare artistică, este important din perspectiva ideii că literatura românească din Ungaria este în primul rând militantă, iar acest volum reprezintă un fragment al istoriei sale culturale (Berény, 1993, p. 24-29). Încercări de poezie are și Isaia B. Bosco, născut în Nermiş în 
1848, el publicând în revistele Familia și Albina Carpaților, singurul său volum de poezii apărut în 1884, Florile inimei, fiind dedicat „mameinațiune" (Berény, 1993, p. 36).

După perioada interbelică, lipsită de orice încercare literară, apare în Ungaria în primele decenii postbelice un grup compact de poeți, din păcate neglijat de istoria și critica literară din România, în interiorul căruia domină două tendințe literare: una clasică, tradițională, care creează mai ales o poezie peisagistă, militantă, și una modernistă, structurală, deschisă spre poetici noi și spre o mai mare libertate a imaginii poetice (Munteanu, 2009, p. 102). Unul dintre aceștia a fost Lucian Magdu (1937-1968), care a publicat versuri în limbile română și maghiară, în mai multe reviste de specialitate, fiind publicat postum în mai multe antologii de poezie românească din Ungaria (Berény, 1995, p. 168), pentru ca în 1991 să-i apară un volum de poezie postumă, Confesiune. Maria Berényi notează că pentru acest poet satul natal reprezintă „locul de refugiu și de contemplație, favorabil regenerării sufletești”, el reîntorcându-se periodic la lumea copilăriei și a satului natal, creând un unviers poetic în care predomină confesiunea străbătută de puternice încărcături emoționale și de o sensibilitate nativă (Berény, 1995, p. 168-169). O altă poetă importantă a comunității românești din Ungaria este Maria Berényi, născută în 1959 la Micherechi, care a îmbinat cu succes activitatea de cercetător științific cu poezia, ea publicând mai multe volume de versuri în limba română și în limba maghiară, încercând să găsească răspuns la întrebările existențiale prin ambele mijloace lingvistice (Munteanu, 2009, p. 21). Volumul de debut a apărut în 1987 și este intitulat Autodefinire, următoarele volume fiind Fără titlu (1989), Pulsul veacului palid (1997) și În pragul noului mileniu (2002). Tiberiu Herdean afirmă că poezia Mariei Berényi este caracterizată de sinceritate, fiind în general de factură confesivă și având o tematică bogată și o puternică încărcătură emoțională și intelectuală (Herdean, 2011, p. 27), iar Elena Rodica Colta remarcă faptul că în poeziile sale este dezvăluită o față intimă, delicată, a intelectualei „bătăioase” din viața de zi cu zi, din versurile poetei desprinzându-se fragilitatea, însingurarea și nesiguranța (Colta, 2002, p. 37).

Profesoara și jurnalista Lucia Borza (1928-2016), pe lângă carierea didactică, scrierea de manuale și activitatea publicistică a ajuns să scrie și literatură pentru copii și poezie. În volumul de versuri Flori târzii, apărut în 1987 și reeditat în 1997 și 2009, construiește un univers al copilăriei utilizând toate componentele sale: căminul familial, imaginea mamei, grădinița, lumea animalelor și a plantelor, culorile naturii, evocarea unor figuri din satul natal (Munteanu, 2009, p. 20). În acest volum se simte preocuparea poetei pentru veșnicele întrebări existențiale legate de viață și moarte, autocunoaștere, identitate, ea evocând satul natal, familia, anii tinereții. Pentru că și-a petrecut o parte din viață la Budapesta, a cunoscut sentimentul dezrădăcinării și al dorului de locurile natale, care reiese puternic din versurile sale (Illyés, 2018, 
p. 21), poeziile aducând cititorului candori nostalgice ale trecutului, trecând de la tematica trecerii timpului, a transformării eului, a regretului cauzat de pierderile celor dragi, până la o poezie a jocului, a copilăriei ca vârstă a nemuririi și a fericirii lipsite de griji (Fenecan, 2003, p. 127). Profesoara Ana Crișan (1937-2012), născută la Otlaca-Pustă, a abordat și ea genul liric, creând o poezie care are la bază tematica evocării, atingând uneori tonuri de umor. În volumul de debut, $C u$ tine, cu voi, apărut în 2002, creațiile lirice pot fi așezate undeva la granița dintre poezia intimă și cea de stare, iar în următoarele volume (Lacrimi și zâmbete -2004, Cuvinte sincere-2007) este creionat mai puternic un topos al satului natal prin locuri și ființe dragi: casa părintească, mama, bunica, viața de familie (Munteanu, 2009, p. 21). Și jurnalistul și folcloristul Alexandru Hoțopan (1937-2007) a publicat în 1997 un volum de poezie, intitulat Din rădăcini comune, în care utilizează formula poeziei-parabolă, pe care o îmbină cu poezia de evocare, la care adaugă ,gustul pentru anecdotă și scenariul cotidian", Cornel Munteanu observând că poetul încearcă să descrie „criza identitarului”, trecând prin înfrângerile și eșecurile inevitabile, pentru a face loc „orgoliului rănit care privește distant și ironic circul comunității dezbinate" (Munteanu, 2009, p. 22). Un alt jurnalist care a fost preocupat de poezie este Petru Anton (1923-1991), care s-a născut pe meleaguri ardelene, la Năsăud, stabilindu-se ulterior în Ungaria. Poemele sale, publicate și în volumul colectiv Muguri, îmbină poezia peisagistă cu meditația existențială iar în altele apare ludicul și anecdoticul (Munteanu, 2009, p. 101).

Literatura românilor din Ungaria nu a produs un prozator de marcă, cu atât mai puțin un romancier, scriitorii abordând mult timp epicul de dimensiuni reduse, textul hibrid, ,la punctul de întâlnire dintre povestirea prelucrată după substanța povestirilor populare autohtone și proza de evocare, memorialistică", fapt care face ca unele texte ficționale să piardă teren în favoarea „documentarului și cotidianului”, un motiv posibil fiind și faptul că mulți dintre scriitori erau și jurnaliști, aceștia practicând formele specifice stilului jurnalistic, reportajul, ancheta sau eseul (Munteanu, 2009, p. 22). Unul dintre cei mai importanți scriitori români din Ungaria este Ilie Ivănuș (1913-1999), el abordând în operele sale atât genul liric cât și genul epic. Ilie Ivănuș s-a născut la Alămor, județul Sibiu, însă s-a stabilit definitiv în Ungaria, unde studiază la Institutul Pedagogic din Budapesta, din 1953 fiind profesor la școala românească din Giula (Berényi, 1999, p. 41). Volumul său de debut a fost unul de poezie, Vioara cu cinci strune, apărut în 1977, acesta fiind primul volum beletristic publicat în rândul românilor din Ungaria, în perioada contemporană. Însă dincolo de poezie, el a fost remarcat în primul rând prin volumele de proză: Dincolo de orizont (nuvele, 1981), Lumea viselor (povestiri, 1991) și Elindultam szép Erdélyböl (Am pornit din frumosul Ardeal - roman autobiografic, 1992), în aceste volume construind o lume imaginară care este mereu modelată pe realitate, scriitorul pornind de la suferința individuală, personală, pentru a ajunge la suferința fiecărui individ, a comunității (Berényi, 1999, p. 41). Scriitoarea Ana Radici Repiský, născută 
în 1964 la Micherechi, creează texte aparținând genului memorialistic, eseurile sale venind din memoria afectivă, ea rememorând întâmplări din adolescență sau scurte anecdote folosite ca pretext de narațiune confesivă (Munteanu, 2009, p. 101-102). Autoarea reușește să redea în cuvinte frământările profunde ale intelectualului român din Ungaria ultimelor decenii ale secolului al XX-lea și a începutului de mileniu, construind astfel o fizionomie proprie comunitătii românești de aici (Gurzău Czeglédi, 2001, p. 46), proza ei fiind născută din iubirea pentru satul natal, Micherechiul fiind văzut ca un centru al lumii, acel „acasă” de care se leagă întreaga ei copilărie (Colta, 2003, p. 61).

Profesorul Petru Popuța, născut în 1931 la Chitighaz, fiind un iubitor al literaturii populare, și-a dorit să o valorifice în literatura cultă, și el abordând genul prozei scurte. Textele sale, publicate de-a lungul anilor în presa românească din Ungaria, au fost inspirate din zona povestitorului popular, el creând o proză densă care poate fi caracterizată prin oralitate și pitoresc, folosindu-se de povestirea populară pentru a construi, în jurul unor situații cunoscute, întâmplări și eroi din actualitate, în volumul din 2006, Amintiri, intâmplări, povești, oferind cititorilor o proză aflată la granița dintre eposul popular și memorialistică (Munteanu, 2009, p. 22-23). Prozatorul și eseistul Gheorghe Santău, născut în 1923 la Chitighaz, abordează și el proza memorialistică, el transformând textul autobiografic în ,plăcerea actului de rememorare", păstrând creațiile la granița dintre textul publicistic și cel literar, printr-o evocare sobră și echilibrată (Munteanu, 2009, p. 23). Şi jurnalistul și prozatorul Vasile Rocsin (1944-2007) a scris în publicațiile vremii texte memorialistice, cu deschidere spre eseu și studiu cultural, care sunt recuperate în volumul Acele vremuri de neuitat, apărut în anul 2004, unde configurează un topos rural al satului său natal, Micherechiul (Munteanu, 2009, p. 24). Trebuie amintită și profesoara și folclorista Ana Varga (1928-1990) care, pe lângă articolele de critică literară din publicațiile românești din Ungaria, a publicat și texte narative: schițe, povestiri, nuvele, reportaje dar și un memorial de călătorie. Ea îmbină proza lirică cu elementele autobiografice, folosind evocarea la persoana I, alături de tehnicile specifice povestirii, în volumul postum Amintiri, mărgăritare, apărut în 1995, fiind recuperate scrieri pe diverse teme sociale, fiind evocați anii de școală, colegii, cu o nostalgie care de multe ori se îmbină cu umorul și ironia, sfârșind adesea într-o meditație personală (Munteanu, 2009, p. 141).

În concluzie, literatura românilor din Ungaria, fie că e vorba de scriitori de limbă română fie de cei bilingvi, poate fi identificată prin câteva specificități datorate contextului social, politic, istoric, lingvistic și cultural în care aceasta s-a dezvoltat. Vorbim despre scriitori aparținând unei minorități etnice, dintr-o comunitate destul de mică și care a trecut în ultima sută de ani prin schimbări majore, care i-au afectat atât viața cotidiană cât și viața culturală, spirituală sau chiar educațională. După momentul 1920 comunitatea românească a trebuit să facă eforturi deosebite pentru a-și reface intelectualitatea, pentru a prezerva tradițiile, limba maternă și identitatea românească. De aceea se poate vorbi 
despre o criză a identității minoritarului care se regăsește în aproape toată literatura românilor din Ungaria, un alt element specific fiind toposul imaginat de scriitori, al locurilor de origine dar și unul social specific, construit prin conviețuirea cu alte naționalități, fiecare împrumutând de la cealaltă diverse specificităţi. De asemenea, este importantă valorificarea creației populare, atât în proza cât și în poezia cultă, de la mijloace artistice la evenimente, personaje, tradiții, descrieri. Iar un alt element specific, în zona prozei, rămâne îmbinarea textului literar cu mijloace specifice reportajului jurnalistic, documentarului sau memorialisticii (Munteanu, 2009, p. 26-27). Nu putem omite și faptul că nu există un grup compact, o generație puternică de scriitori care să se afirme în literatura de adopție, neexistând nicio asociație literară sau un cenaclu literar, scriitorii afirmându-se prin inițiative individuale, aceștia neintegrându-se nici în organizații de breaslă din România, nefiind recuperați astfel de întreaga literatură română (Munteanu, 2009, p. 27).

Foarte important pentru literatura românilor din Ungaria este faptul că au existat în perioada postbelică centre de românitate care iau iniţiativa înființării unor reviste de cultură sau a publicării textelor literare ale scriitorilor români din interiorul comunității: la Giula, sub egida Editurii NOI sunt publicate texte ale scriitorilor de limbă română, la Budapesta sunt publicate texte cu sprijinul Editurii Didactice, iar la Seghedin există sprijinul Catedrei de Limba Română de la universitate (Munteanu, 2009, p. 30-31). Trebuie menționat și un ultim aspect, faptul că din inventarul ideatic și imagistic al literaturii românilor din Ungaria lipsește toposul din România, el apărând eventual doar prin figuri ale unor oameni care au marcat copilăria și tinerețea unor scriitori veniți de acolo, cum ar fi cazul prozelor lui Ilie Ivănuş, care descrie Alămorul Sibiului sau imaginea atât de dragă a bunicii care l-a crescut (Munteanu, 2009, p. 27). Concluzia care se poate desprinde este că scriitorii români din Ungaria simt că aparțin unei comunități românești care se disociază de cea din România, ei încercând să exprime în operele lor trăirile, sentimentele, ideile și imaginile artistice specifice unei comunități etnice minoritare, cu problemele ei, cu greutățile ei și cu viața cotidiană, culturală, spirituală, socială specifică, în care ideea de românitate reiese în primul rând din limba maternă folosită, dar mai puțin din împărtășirea unor idealuri și trăsături comune cu conaționalii din România.

\section{Referințe bibliografice:}

1. BERÉNYI, Maria. In memoriam Ilie Ivănuş (1913-1999). În: Lumina, Publicaţia Institutului de Cercetări al Românilor din Ungaria. 1999, p. 41.

2. BERÉNY, Maria. Isaia B. Bosco - notar adjunct şi poet în Chitighaz. În: Chitighaz. Pagini istorico-culturale, Publicație a Comunității Cercetătorilor și Creatorilor Români. Budapesta, 1993, p. 36. 
3. BERÉNYI, Maria. Poetul Lucian Magdu. În: Bătania - Pagini istoricoculturale, Publicație a Institutului de Cercetări al Românilor din Ungaria. Budapesta, 1995, p. 168-169.

4. BERÉNY, Maria. Poeziile lui Iosif Ioan Ardelean. În: Chitighaz. Pagini istorico-culturale, Publicație a Comunității Cercetătorilor și Creatorilor Români. Budapesta, 1993, p. 24-29.

5. BUCIN, Mihaela. Perspectivă diacronică asupra epicii narative orale a românilor din Ungaria. În: Din tradițile populare ale românilor din Ungaria. 1999, nr. 12, p. 10.

6. COLTA, Elena Rodica. Melancolica tristețe a Mariei. În: Lumina, Publicația Institutului de Cercetări al Românilor din Ungaria. 2002, p. 37.

7. COLTA, Elena Rodica. „Plopi la capătul lumii” (recenzie). În: Lumina, Publicația Institutului de Cercetări al Românilor din Ungaria. 2003, p. 61.

8. COMAN, Mihai. Introducere în sistemul mass-media, Iași, 1999. 1985.

9. DOMOKOS, Sámuel. Magyar-román irodalmi kapcsolatok, Budapesta,

10. FENECAN, Daiana. Redescoperirea cuvântului primăvăratic. În: România km 0. Revistă de cultură. 2003, Anul IV, nr. 1-2 (6-7), p. 127.

11. GIRAUD, Michel, Etnicitatea ca necesitate și ca obstacol. În: FERRÉOL, Gilles (editor). Cetățenie și integrare socială. București, 1999, p. 64.

12. GURZĂU CZEGLÉDI, Maria. Ana Radici Repiský: "Rupte din suflet” (recenzie). În: Lumina, Publicația Institutului de Cercetări al Românilor din Ungaria. 2001, p. 46.

13. HEDEȘAN, Otilia (coord.). Dacă n-ar vu fi, nu s-ar vu povesti... Antologie a povestitorilor români din Ungaria. Timișoara, 2007.

14. HERDEAN, Tiberiu, Poezia Mariei Berényi. În: Lumina, Publicația Institutului de Cercetări al Românilor din Ungaria. 2011, p. 27.

15. HOȚOPAN, Alexandru. Împăratu Roșu și Împăratu Alb (Poveștile lui Teodor Șimonca). Budapesta, 1982.

16. ILLYÉS, Edda. De doi ani nu mai e printre noi Lucia Borza. În: Lumina, Publicația Institutului de Cercetări al Românilor din Ungaria. 2018, p. 21.

17. LÉVI-STRAUSS, Claude. Rasă și istorie. Iași, ed. a II-a, 2001.

18. MIHĂILESCU, Vintilă. Antropologie. Cinci introduceri. Iași, 2007.

19. MUNTEANU, Cornel. Românii din Ungaria, II. Literatura (1950-2008). Cluj Napoca, 2009.

20. MUNTEANU, Cornel. Românii din Ungaria, I. Presa (1950-2005). Gyula, 2006.

21. PIERROT, Alain. Multiculturalismul: un limbaj considerat concret în mod fals. In: FERRÉOL, Gilles (editor). Cetățenie și integrare socială. București, 1999, p. 144-152.

22. RADKOWSKI, Georges-Hubert. Antropologie Generală. Timișoara, 2000.

23. RALIADE, Rodica, NUBERT CHET,AN, Mihaela. Lecturi identitare. Români din Ungaria - studii de caz -. București, 2004.

24. SILAGHI, Petru (redactor), Muguri. Scrieri ale autorilor români din Ungaria. Giula, 1973. 